\title{
The Role of Work Experience in Studying and Career Development in Tourism: A Case Study of Tourism and Hospitality Students from Northern Poland
}

\author{
Aleksandra Grobelna, Anna Dolot
}

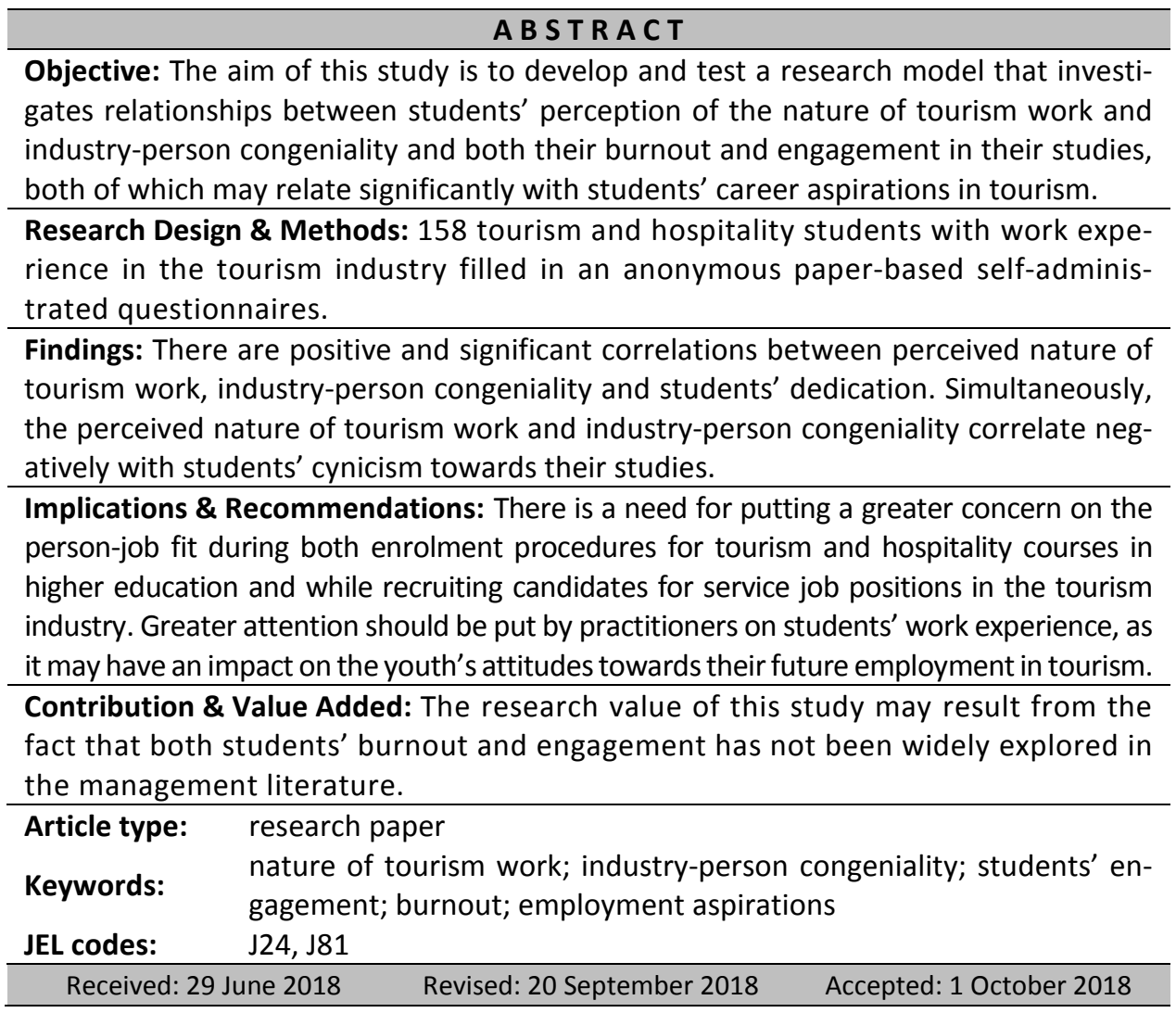

\section{Suggested citation:}

Grobelna, A., \& Dolot, A. (2018). The Role of Work Experience in Studying and Career Development in Tourism: A Case Study of Tourism and Hospitality Students from Northern Poland. Entrepreneurial Business and Economics Review, 6(4), 217-229. https://doi.org/10.15678/EBER.2018.060412 


\section{INTRODUCTION}

The importance of educated, enthusiastic and committed workforce cannot be underestimated for service industries in general, and the tourism industry in particular (Kusluvan \& Kusluvan, 2000, p. 253). This industry is considered as one of the major sectors in which human resources are seen as significant and highly dependent on professional education (Tuna, Kanten, Yeşiltaş, Kanten, \& Alparslan, 2014, p. 139). Although it seems that nowadays the employee's development process is becoming long-life, this process - of actual adult man education - starts during higher education.

The concept of students engaged in part-time and full-time employment while studying is increasingly commonplace (Watts \& Pickering, 2000; Jogaratnam \& Buchanan, 2004; Barron, 2007; Uludağ \& Yaratan, 2010). Scientific papers show that there is an increasing number of students undertaking employment during the term (Watts \& Pickering, 2000). A large proportion of students must handle one or more jobs to help pay for college or university expenses while attempting to balance curricular and programme demands, as it requires completion of internships as a part of degree requirements (Jogaratnam \& Buchanan, 2004; Barron, 2007). The abovementioned research concerns tourism and hospitality students. Internships, as well as first jobs, give students an opportunity to be a part of the tourism industry, gain experience but additional activities undertaken during one's studies are as well a kind of hardship. The tourism and hotel sector faces numerous difficulties that may influence the student's perception of work itself. Meanwhile, an image of a particular industry will have a major effect on potential recruits' perception of the industry, which will impact the quality and quantity of future staff (Riley, Ladkin, \& Szivas, 2002).

The aim of this article is developing and testing a research model that investigates relationships between the perception of the nature of tourism work and industry-person congeniality and students' engagement in their studies manifested in their dedication to the undertaken studies and burnout manifested in students' cynical attitude towards their studies. Additionally, the consequences of students' engagement and burnout for their employment aspiration in tourism are also analysed.

The structure of this article is as follows: at the beginning the literature review is presented. Then the research concept, data collection procedure and measurements are discussed. Important part of this article is the presentation and discussion of the results.

\section{LITERATURE REVIEW AND THEORY}

\section{Nature of Tourism Work}

The image of the tourism industry seems to have two sides. On the one hand, the industry is seen as a glamorous one, while on the other hand it is deemed as struggling with a wide variety of difficulties (Riley, Ladkin, \& Szivas, 2002). Working shifts, as well as working hours and days (also public holidays) make it difficult to establish a work-life balance and constitute a disadvantage (Wan, Wong, \& Kong, 2014). Low wages constitute a significant problem, especially in the hospitality sector (Poulston, 2008). Another significant obstacle is lack or limited employee training (Davidson, Timo, \& Wang, 2010; Dolot, 2017) in parallel with existing training areas (Peters \& Buhalis, 2004). In consequence, the hospitality sector has a rather negative image on the labour market in general (Dickinson \& Ineson, 1993), 
but also in the eyes of hospitality students (Jenkins, 2001), and it struggles with difficulties in recruiting, keeping employees, resulting in staff shortages (Zhang Qiu \& Lam, 2004) and high staff turnover (Davidson, Timo, \& Wang, 2010).

Hospitality and tourism students may confront the burnout syndrome which may lead to more serious academic erosion than in the case of students of other disciplines (Uludağ \& Yaratan, 2010, pp. 13-14). As burnout is defined as a three-dimensional syndrome of emotional exhaustion, lack of personal accomplishment and depersonalisation, cynical attitudes towards one's job is a good example of this last dimension (Maslach \& Jackson, 1981). The term of burnout is also defined in the context of students: students' burnout is 'feeling exhausted because of study demands (exhaustion), having a cynical and detached attitude towards one's schoolwork (cynicism), and feeling incompetent as a student (reduced efficacy also known as reduced academic efficacy)' (Schaufeli, Martinez, Marques-Pinto, Salanova, \& Bakker, 2002, p. 465). As the specialists highlight, burnout emerges gradually in the shape of emotional burnout, cynicism, and then low personal accomplishment (Duru, Duru, \& Balkis, 2014).

There is already research in the area of cynicism negatively related to dedication (Schaufeli \& Bakker, 2004), negative relationships between exhaustion and vigour, cynicism and dedication (Bakker, Demerouti, \& Schaufeli, 2005) or cynicism negatively associated with students' dedication (Uludağ \& Yaratan, 2010).

An important issue emerges here: students' attitude already formed during the educational process constitutes a minority of their professional attitude in the tourism and hospitality sector where dedication as well as personality traits are crucial in direct contact with the tourism and hospitality guests. Therefore, it is a posit:

H1: The perceived nature of work in tourism is positively related to students' dedication to their studies ( $\mathrm{H} 1 \mathrm{a}$ ) and negatively related to their cynicism towards their studies (H1b).

\section{Industry-person Congeniality in the Tourism and Hospitality Sector}

One of important elements that influences the attitude, career plans and employment aspirations in tourism and hospitality is industry-person congeniality (Kusluvan \& Kusluvan, 2000; Teng, 2008). Dimensions that may define industry-person congeniality is confidence that someone's personality and character match closely the types of jobs available in the industry, confidence that one will get an opportunity to use their skills and abilities working in the industry, that one will get pleasure out of seeing satisfied customers and finally that one will find pleasure working in the industry.

Industry-person congeniality is significantly important in service industries in general but in the tourism and hospitality sector in particular. Most services in this sector are based on human performance, services are produced and consumed simultaneously in a face-toface exchange situation and employees and customers are close physically and psychologically (Kusluvan \& Kusluvan, 2000, p. 253). Service providers have to rely heavily on the competence and ability of their employees to understand consumer requirements and react in a timely and appropriate manner (Ghobadian, Speller, \& Jones, 1994), including dealing with emotional expressions of customers (Rafaeli, 1989). That demands special character, abilities and skills that employees should posses. The tourism and hotel industry is 
classified as a high service encounter one, which means that employees contact customers more frequently and widely (Lin, 2007).

In line with the abovementioned theory the following hypothesis is proposed:

H2: The perceived industry-person congeniality is positively related to students' dedication to their studies ( $\mathrm{H} 2 \mathrm{a}$ ) and negatively related to their cynicism towards their studies $(\mathrm{H} 2 \mathrm{~b})$.

\section{Tourism Students' Attitude, Career Plans and Employment Aspirations}

Not only is the image and nature of the tourism industry ambiguous but also tourism students' and graduates' employment aspirations are. Ross's research shows a positive attitude, career plans and employment aspirations of tourism students and graduates. He highlighted that school leavers interested in tourism and hospitality positions generally placed a higher than average value on achievement in their prospective professional life (1991). He emphasised that Australian secondary school students had a high level of interest in management positions in the tourism and hospitality sector (1992). Positive experience and perceptions of the hospitality industry were the main reasons for UK hotel and catering graduates being attracted to studying hospitality management (Purcell \& Quinn, 1996).

Simultaneously, there is research investigating the attitude, career plans and employment aspirations of people who currently work in the tourism and hospitality sector. Choy's study (1995) showed that large majority of Hawai tourism industry workers were satisfied with their jobs.

Studies show students' and graduates' negative attitude, career plans and employment aspirations in the tourism and hospitality sector. Pavesic and Brymer (1990) highlight that a substantial number of graduates leave tourism jobs due to low job satisfaction, poor work conditions and lack of motivating factors. It seems to be specially observed nowadays. Recent studies discuss the issues pertaining to students' commitment to join the hospitality industry after their graduation (Kusluvan \& Kusluvan, 2000).

Career experiences and perceptions of graduates in the tourism and hospitality sector are investigated worldwide: in the United States of America (Jogaratnam \& Buchanan, 2004; Richardson \& Thomas, 2012), Australia (Richardson, 2010), China (Jiang \& Tribe, 2009), Taiwan (Teng, 2008), Malaysia (Richardson \& Butler, 2012), Turkey (Kusluvan \& Kusluvan, 2000), Western (Jenkins, 2001) and Southern Europe (Uludağ \& Yaratan, 2010).

It seems that there is a gap in this kind of studies in Central Europe, especially in the abovementioned dimensions: the nature of work in tourism, students' dedication to their studies, students' cynicism towards their studies, and students' aspirations for employment in the tourism industry. That is why, the last two hypotheses are:

H3: Students' dedication to their studies is positively related to their aspirations for employment in the tourism industry.

H4: Students' cynicism towards their studies is negatively related to their aspirations for employment in the tourism industry. 


\section{MATERIAL AND METHODS}

\section{Research Concept}

This study is part of an integrated research project on tourism and hospitality students' perception of their future employment in the industry (Grobelna \& Tokarz-Kocik, 2018).

This study develops and tests a research model (Figure 1 ) that investigates relationships between the perception of the nature of tourism work (NAT_WORK) and industry-person congeniality (I-P_CONG) and students' engagement in their studies manifested in their dedication (S_DED) to the undertaken studies and burnout manifested in students' cynical attitude (S_CY) towards their studies. Additionally, the consequences of students' engagement and burnout for their employment aspiration in tourism (EMP_ASPi) are analysed.

The conceptual model and all the hypothesised relationships are presented in Figure 1.

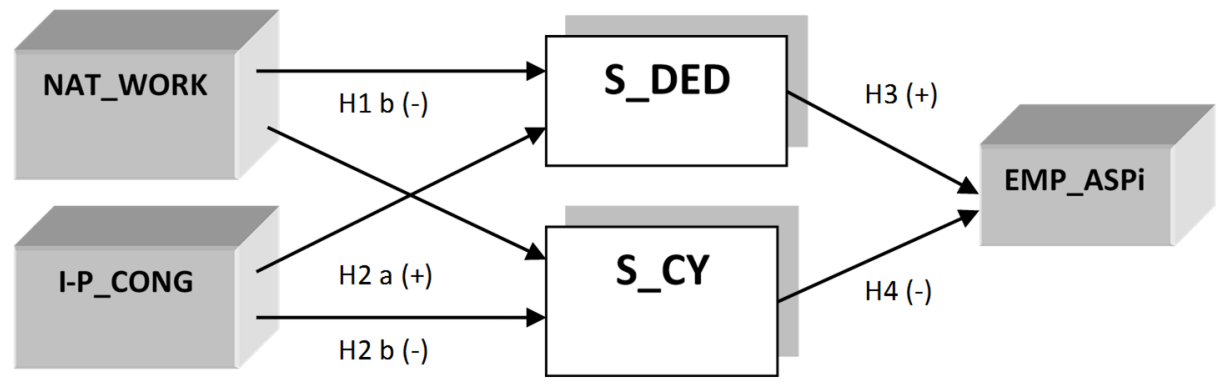

Figure 1. Conceptual Model

Note: NAT_WORK (Nature of Work); I-P_CONG (Industry-Person Congeniality); S_DED (Student's Dedication); S_CY (Student's Cynicism); EMP_ASPi (Employment Aspirations) Source: own elaboration.

\section{Data Collection Procedure}

In this study purposive sampling was chosen. The research was conducted among tourism and hospitality $(\mathrm{T} \& \mathrm{H})$ students who declared their work experience in tourism. As literature emphasises, students with work experience may have more realistic views regarding their future jobs and may have been ready to make their job decision (see Teng, 2008). This is also proved by the results of previous works which showed that students' early work experience may have an impact on their attitudes towards and perceptions of the career in the tourism and/or hospitality industry (e.g. Barron, Maxwell, Broadbridge, \& Ogden, 2007; 2010). For example, in a study of Grobelna and Marciszewska (2016a), it was found that tourism and hospitality students who were currently working in the industry were more likely than others to claim a good understanding of the nature of work in their learning fields. Therefore, it sounds reasonable that this group of respondents, having observation and experience of the real work, may provide adequate feedback on the research problems being under investigation of this study.

Three higher education institutions (HEI), both public and private, were identified as the target group for this study for the following reasons. First, all of them have the educational offer in the tourism and/or hospitality field and agreed to participate in the study. Second, they were located in the Tricity agglomeration that is perceived as a big 
economic and academic centre of the Pomerania region (Gospodarka, 2010), that educates employees for the needs of the tourism industry and offers new jobs in this field (Grobelna \& Marciszewska, 2016b). Thus, choosing HEl located in the Tricity agglomeration location seems justified in the context of this study.

The research was conducted between January and February 2018. The auditorium survey technique was applied to gather the data. Respondents were requested to fill in the paper-based self-administrated questionnaires that were distributed to students during the teaching time agreed with the lecturers of the participating $\mathrm{HEI}$. The research was conducted following a detailed explanation of its purpose. Additionally, the students were informed that their participation was voluntary and was not a formal part of their obligatory study programme (Barron et al., 2007). All questionnaires were anonymous, and students were assured of the confidentiality of their answers.

It is worth noticing that self-administrated questionnaires are considered to be some of the most popular tools in social research with some added advantages (see Gray Williamson, Karp, \& Dalphin, 2007). There is no pressure on the respondents to reply immediately, as it gives them as much time as they need to consider each survey question carefully.

All the above aspects, including the controlled nature of the questionnaire administration during formal class time and under supervision of the researcher, contributed to achieving a maximum response (Barron, 2007). As a result, in this study 158 usable surveys were obtained after deleting any incomplete questionnaires (14 surveys), resulting in a response rate of $91.86 \%$.

\section{Measurement}

To operationalise the study constructs, the existing and well-established scales were used from the relevant literature and previous studies. To measure the perceived nature of work in tourism (NAT_WORK) and students' industry-person congeniality (I_P CONG), selected items were used from Kusluvan and Kusluvan (2000) who developed a multi-dimensional and multi-item attitude scale to measure students' attitudes towards work in the tourism industry. In this study, five and six items were used respectively for NAT_WORK (items No. 1, 2, 4, 5, 8) and for I_P CONG (items No. 2, 4, 6, 7, 9, 10). Those items were chosen carefully on the basis on detailed literature review and in reference to the best of the researchers' knowledge and their expertise in the field of tourism and hospitality industry, taking Poland as its setting. It is worth noticing that Kusluvan and Kusluvan' attitude scale (2000), or its selected items, were also used in many previous studies among tourism and/or hospitality students in different geographical settings, including Australia (Richardson, 2010), Taiwan (Teng, 2008) or the United States (Richardson, \& Thomas, 2012). Sample items are: 'I find jobs in the tourism industry interesting' (NAT_WORK) or 'My character fits to working in the tourism industry' (I-P_CONG).

Cynicism (S_CY) was measured via four items from the Maslach Burnout Inventory-Student Survey (MBI-SS; Schaufeli et al., 2002). A sample item is: 'I have become less enthusiastic about my studies'. The empirical attention of this study is also shifted toward the opposite of burnout, i.e. engagement (Schaufeli et al., 2002). In the context of this study, students' engagement can be perceived as their positive and fulfilling state of mind characterised by vigour, dedication and involvement in their studies (see Schaufeli et al., 2002). Dedication (S_DED), as one of the engagement's dimensions, was used and assessed via five items from the Utrecht Work Engagement Scale for Students (UWES-S; Schaufeli et al., 2002). A sample 
item is 'I find my studies to be full of meaning and purpose'. MBI-SS and UWES-S scales were successfully applied and tested in a study by Uludag and Yaratan (2010) among undergraduate hospitality and tourism students in Northern Cyprus.

Students' employment aspirations (EMP_ASPi) were assessed via four items from Teng (2008), who applied them successfully to measure hospitality employment aspirations in a study among post-internship undergraduate hospitality seniors in Taiwan. However, given the fact that in this study students' employment aspirations referred to their attitudes in terms of the commitment to the tourism industry in general, the items used in this study were reworded accordingly. A sample is: 'I would like to work in the tourism industry after graduation'.

Responses to the scale items were elicited on five-point scales, ranging from (1) strongly disagree to (5) strongly agree. Some items were also reverse-coded according to their cited sources. Higher scores indicated higher industry-person congeniality, more favourable perception of the nature of work in tourism, higher employment aspirations in tourism, and also higher students' cynicism towards their studies. Demographic data were also collected to ascertain the respondents' profiles.

Before collecting data, the survey instrument was administrated to a pilot sample consisting of T\&H students for its verification. Feedback from the pilot group confirmed no difficulties with good understanding of the scale items in the survey instrument.

In this study, descriptive statistics and reliability analysis were performed. To verify the relationship between the study variables, Pearson's correlation was applied. The collected data were analysed using Statistical Package for Social Sciences (SPSS), version 25.

\section{RESULTS AND DISCUSSION}

The majority of the study respondents were females (81.6\%). Nearly half of the participants (49.4\%) were between $22-25$ years old, and slightly fewer (43\%) declared their age between $18-21$ years $(43 \%)$. The remaining ones $(7.6 \%)$ were 26 years old or older. All of the surveyed students have rich work experience, indicating different sectors of tourism: food \& beverage (61.4\%), hospitality services (43\%), travel agencies/tour operators (7\%), tour guiding $(4.4 \%)$ or transport services (3.2\%). All respondents were bachelor students.

To test for internal consistency of the scales and their reliability, Cronbach's alpha was calculated (Nunnally, 1978). The reliability values for the scales were as follows: 0.78 for EMP_ASPi; 0.83 for S_DED; 0.85 for S_CY; 0.78 for I_P CONG and 0.55 for NAT_WORK. Although the last coefficient alpha (for NAT_WORK) is below the recommended value of 0.7 , similar or even lower reliability values were still regarded as sufficient in previous studies, given the early stages of exploratory research (Kwok, Adams, \& Feng, 2012; Richardson, 2010; Richardson \& Thomas, 2012).

Means and standard deviations of the study variables are presented in Table 1 . It is worth noticing that the respondents' (average) study dedication level was 3.42. They manifested their cynicism towards the undertaken studies at the level of 2.83. Thus, it can be stated that students in this study perceive themselves more dedicated towards their current studies than displaying cynical attitudes to them. The average perceived nature of tourism work and industry-person congeniality scores in this study was 3.55 and 3.83, respectively. A higher industry-person congeniality score shows that the students seem to 
perceive themselves as quite well fitted to the service jobs in tourism. The specific nature of work in tourism is perceived in slightly less favourable terms.

Table 1. Descriptive statistics

\begin{tabular}{|c|c|c|c|c|c|}
\hline Variable / Measure & NAT_WORK & I-P_CONG & S_DED & S_CY & EMP_ASPi \\
\hline Mean & 3.55 & 3.83 & 3.42 & 2.83 & 3.60 \\
\hline Std. dev. & 0.53 & 0.63 & 0.75 & 0.94 & 0.86 \\
\hline
\end{tabular}

Source: own study.

As depicted in Figure 2, there are positive and significant correlations between perceived NAT_WORK, I-P_CON and S_DED, providing empirical support for Hypotheses $1 \mathrm{a}$ and $2 \mathrm{a}$, respectively. The more favourable students' perception of the nature of tourism work is, and the more they feel fitted to the demands of tourism work, the more dedicated to their studies they become.

The findings of this study also revealed negative and significant correlations between perceived NAT_WORK, I-P_CONG and S_CY, providing empirical support for Hypotheses $1 \mathrm{~b}$ and $2 \mathrm{~b}$. The more negative perception of tourism work respondents of this study hold, the lower their interest in their current studies is. Such students are becoming more cynical towards their studies, losing their purpose and meaning. Similarly, the lower the students' conviction about their being suited for customer-oriented service jobs in tourism, the more doubtful they feel about potential usefulness of their studies and their significance.

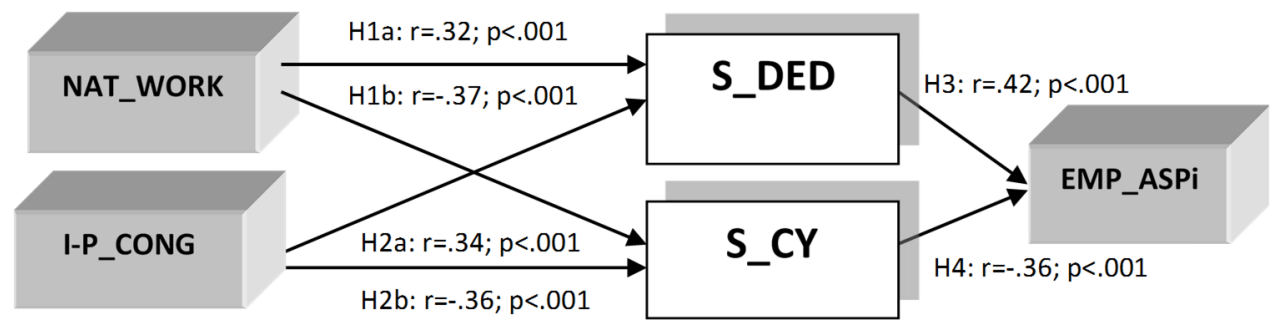

Figure 2. Verified model

Note: NAT_WORK (Nature of Work); I-P_CONG (Industry-Person Congeniality); S_DED (Students' Dedication); S_CY (Students' Cynicism); EMP_ASPi (Employment Aspirations)

Source: own elaboration.

Finally, it was revealed that an increase in both S_DED and S_CY may significantly relate to students' employment aspirations in tourism, but in different directions, providing support for hypotheses 3 and 4 . The more students are dedicated towards their current studies, the more optimistic they are towards their future employment in tourism. This is in contrast to those who are cynical about their studies and who lose their purpose, as they may not have serious aspirations for employment in tourism.

In post hoc analysis, it was also revealed that there is quite a strong and positive correlation between I-P_CONG and NAT_WORK $(r=0.55 ; p<0.001)$. This may show that the greater students' agreement with being suited for the requirements of service jobs in tourism, the more favourably they perceive the nature of work in tourism. 
As hypothesised, both NAT_WORK and I-P_CONG may play an important role in increasing students' dedication towards their current study in tourism and/or hospitality fields. It may suggest that tourism and hospitality students who have a favourable perception of the nature of tourism work and perceive a better fit with it, feel greater enthusiasm about their studies, inspiration and pride in them. Such students may also have higher aspirations for employment in the tourism industry, in contrast to those who are not convinced about being suited to the service demands of tourism work and perceive its nature in less favourable light. Summarising, both the perceived nature of the tourism work and person-job fit can be perceived in this study as key factors that may determine the attractiveness of the undertaken studies, which in turn may affect students' attitudes and perceptions of their careers in tourism.

This study also provides support for the findings of previous studies where the demanding nature of tourism work and lack of confidence in being suitable for work in tourism were indicated by students among the main reasons for the lack of their commitment to work in the tourism industry after graduation (see e.g. Grobelna \& Marciszewska, 2016a). Similarly, in Teng's study (2008) it was shown, among others, that both NAT_WORK and I-P_CONG were found among predictors of students' employment aspiration. Specifically, it was revealed that students hold unfavourable attitudes towards getting hospitality jobs after graduation being least satisfied with the nature of that work. In Kusluvan and Kusluvan's work (2000), most respondents complained that they 'felt as a slave' (p. 257) while working in tourism. Similar results were achieved by Richardson and Thomas (2012) in their study among hospitality and tourism students. By contrast, if students feel that their personal traits fit tourism jobs well, they may wish to follow careers in the field of education such as tourism, as shown in Jiang and Tribe's (2009) work.

As to theoretical contributions, this study adds to the growing body of two main research streams. One of them covers issues of students' attitudes and perceptions towards their future career in tourism and/or hospitality industry (e.g. Jiang \& Tribe, 2009; Kusluvan \& Kusluvan, 2000; Richardson, 2010; Richardson \& Butler, 2012; Teng, 2008). The other one refers to the burnout and engagement in students (e.g. Schaufeli et al., 2002; Uludağ \& Yaratan, 2010) and constitutes a particularly interesting area of new research, as a study examining burnout among T\&H students (non-occupational individuals) 'expands the original theory of burnout that deals mainly with people who have occupations' (Uludağ \& Yaratan, 2010, p. 14). The research value of this study may result from the fact that, to the best of authors' knowledge, this study is among the first to make an attempt to link study areas from two main research streams into one empirical investigation and analyse the proposed relationships in one conceptual model, expanding study results to the new context of tourism and hospitality students in Northern Poland.

\section{CONCLUSIONS}

The research concept reflects an integrated approach that should contribute to a better understanding of how job-related factors perceived by T\&H students may shape their attitudes towards undertaken studies, and how they may relate to students' perception of the tourism industry attractiveness as a place of their future employment. The study also aimed to answer calls for research in the current understanding of the perception and attitudes of young 
people to their potential careers in the tourism industry (Richardson, 2010), as this research area has still received little empirical attention (Kusluvan \& Kusluvan, 2000).

This study results may emphasize a need for putting a greater concern on the personjob fit during both enrolment procedures for tourism and hospitality courses in higher education and while recruiting candidates for service job positions in the tourism industry. Moreover, given the perceived nature of tourism work, practitioners are recommended to take greater care of students' work experience, as it may have a potential impact on youth's attitudes towards their education in tourism and their future employment in the sector. Similarly, educators are suggested to provide students with more opportunities for practical learning, as it may shape students' realistic expectations towards work in tourism and may help them to be more aware of the specific nature and requirements of tourism jobs. This may include a case study and role playing used during academic classes. Both methods should be based on real, especially challenging business cases.

This study has some limitations. Due to the fact that the research was conducted only among students of three HEI from the Tricity, the results of this study cannot be generalised. Future studies with a larger sample of tourism and hospitality students from other $\mathrm{HEI}$ located in different geographical regions of Poland are recommended. However, in spite of that limitation, the findings of this study can constitute a basis for discussion and a starting point for future extended research on factors influencing students' attitudes towards and perception of their future employment in tourism. It could be interesting to add to the conceptual model also other variables coming from the area of education (e.g. length of practical training, teaching techniques, type of study, etc.), industry (e.g. empowerment, training, rewards, etc.) and individuals including their personality traits. All these aspects could potentially affect students' attitudes and perceptions towards both their studies and careers in the fields of education.

\section{REFERENCES}

Bakker, A.B., Demerouti, E., \& Schaufeli, B.W. (2005). The crossover of burnout and work engagement among working couples. Human Relations, 58, 661-689. https://doi.org/10.1177/0018726705055967

Barron, P., Maxwell, G., Broadbridge, A., \& Ogden, S. (2007). Careers in Hospitality Management: Generation Y's Experiences and Perceptions. Journal of Hospitality and Tourism Management, 14(2), 119-128. https://doi.org/10.1375/jhtm.14.2.119

Barron, P. (2007). Hospitality and Tourism Students' Part-time Employment: Patterns, Benefits and Recognition. Journal of Hospitality, Leisure, Sport and Tourism Education, 6(2), 40-54. https://doi.org/10.3794/johlste.62.150

Choy, D.J.L. (1995). The quality of tourism employment. Tourism Management, 16(2), 129-139.

Davidson, M.C.G, Timo, N., \& Wang, Y. (2010). How much does labour turnover cost? A case study of Australian four- and five-star hotels. International Journal of Contemporary Hospitality Management, 22(4), 451-466. https://doi.org/10.1108/09596111011042686

Dickinson, A., \& Ineson, E.M. (1993). The Selection of Quality Operative Staff in the Hotel Sector. International Journal of Contemporary Hospitality Management, 5(1), 16-21. https://doi.org/https://doi.org/10.1108/09596119310026251 
Dolot, A. (2017). Coaching Process and Its Influence on Employees' Competencies in the Hospitality Sector - Case Study. International Journal of Contemporary Management, 16(2), 75-98. https://doi.org/10.4467/24498939IJCM.17.011.7524

Duru, E., Duru, S., \& Balkis, M. (2014). Analysis of Relationships among Burnout, Academic Achievement, and Self-regulation. Educational Sciences: Theory \& Practice, 14(4), 1274-1284. https://doi.org/10.12738/estp.2014.4.2050

Ghobadian, A., Speller, S., \& Jones, M. (1994). Service Quality: Concepts and Models. International Journal of Quality \& Reliability Management, 11(9), 43-66. https://doi.org/10.1108/02656719410074297

Gospodarka. Województwo_Pomorskie (2010). Agencja Rozwoju Pomorza S.A. Retrieved from www.paih.gov.pl/files/?id_plik=12088 on April 17, 2018.

Gray, P.S., Williamson, J.B., Karp, D.A., \& Dalphin, J.R. (2007). The Research Imagination. An introduction to qualitative and quantitative methods. Cambridge: University Press.

Grobelna, A., \& Tokarz-Kocik, A. (2018). Relacje społeczne i ekonomiczne doświadczane w pracy a wizerunek przedsiębiorstw turystycznych jako pracodawców, [article under review].

Grobelna, A., \& Marciszewska, B. (2016a). Undergraduate students' attitudes towards their future jobs in the tourism sector: challenges facing educators and business. In D. Vasilenko \& N. Khazieva (Eds.), Proceedings of The 4th International Conference on Management, Leadership and Governance (pp. 138-145). Academic Conferences and Publishing International Limited, UK.

Grobelna, A., \& Marciszewska, B. (2016b). Work motivation of tourism and hospitality students: implications for human resource management. In C. Bagnoli, Ch. Mio, A. Garlatti, \& M. Massaro (Eds.), Proceedings of the 8th European Conference on Intellectual Capital (pp. 95-103). Academic Conferences and Publishing International Limited, UK.

Jenkins, A.K. (2001). Making a career of it? Hospitality students' future perspectives: an Anglo-Dutch study. International Journal of Contemporary Hospitality Management, 13(1), 13-20. https://doi.org/10.1108/09596110110365599

Jiang, B., \& Tribe, J. (2009). Tourism jobs - short-lived professions': Student attitudes towards tourism careers in China. Journal of Hospitality, Leisure, Sport and Tourism Education, 8(1), 4-19. https://doi.org/10.3794/johlste.81.168

Jogaratnam, G., \& Buchanan, P. (2004). Balancing the demands of school and work: Stress and employed hospitality students. International Journal of Contemporary Hospitality Management, 16(4), 237-245. https://doi.org/10.1108/09596110410537397

Kusluvan, S., \& Kusluvan, Z. (2000). Perceptions and attitudes of undergraduate tourism students towards working in the tourism industry in Turkey. Tourism Management, 21, 251-269. https://doi.org/10.1016/S0261-5177(99)00057-6

Kwok, L., Adams, Ch.R., \& Feng, D. (2012). A comparison of graduating seniors who receive job offers and those who do not according to hospitality recruiters' selection criteria. International Journal of Hospitality Management, 31(2), 500-510. https://doi.org/10.1016/j.ijhm. 2011.07.008

Lin, W-B., (2007). The exploration of customer satisfaction model from a comprehensive perspective. Expert Systems with Applications, 33(1), 110-121. https://doi.org/10.1016/j.eswa.2006.04.021

Maslach, C., \& Jackson, S.E. (1981). The measurement of experienced burnout. Journal of Occupational Behaviour, 2, 99-113. https://doi.org/10.1002/job.4030020205

Nunnally, J.C. (1978). Psychometric Theory, 2nd ed. New York: McGraw-Hill Book Company.

Pavesic, D.V, \& Brymer, R.A. (1990). Job Satisfaction: What's Happening to the Young Managers?. Cornell Hospitality Quarterly, 30(4), 90-96. https://doi.org/10.1177/001088049003000420

Peters, M., \& Buhalis, D. (2004). Family hotel businesses: strategic planning and the need for education and training. Education + Training, 46(8/9), 406-415. https://doi.org/10.1108/00400910410569524 
Poulston, J. (2008). Hospitality workplace problems and poor training: a close relationship. International Journal of Contemporary Hospitality Management, 20(4), 412-427. https://doi.org/10.1108/09596110810873525

Purcell, K., \& Quinn, J. (1996). Exploring the education-employment equation in hospitality management: a comparison of graduates and HND's. International Journal of Hospitality Management, 15(1), 51-68.

Rafaeli, A. (1989). When clerks meet customers: a test of variables related to emotional expressions on the job. Journal of Applied Psychology, 74(3), 385-93.

Richardson, S. (2010). Tourism and hospitality students' perceptions of a career in the industry: a comparison of domestic (Australian) students and international students studying in Australia. Journal of Hospitality and Tourism Management, 17(1), 1-11. https://doi.org/10.1375/jhtm.17.1.1

Richardson, S., \& Butler, G. (2012). Attitudes of Malaysian Tourism and Hospitality Students' towards a Career in the Industry. Asia Pacific Journal of Tourism Research, 17(3), 262-276. https://doi.org/10.1080/10941665.2011.625430

Richardson, S., \& Thomas, N.J. (2012). Utilising Generation Y: United States hospitality and tourism students' perceptions of careers in the industry. Journal of Hospitality and Tourism Management, 19(1), 102-114. https://doi.org/10.1017/jht.2012.12

Riley, M., Ladkin, A., \& Szivas, E. (2002). Tourism Employment: Analysis and Planning. Sydney: Channel View Publications.

Ross, G.F. (1991). Correlates of work responses in the tourism industry. Psychological Reports, 68, 1079-1089.

Ross, G.F. (1992). School leavers and their perceptions of employment in the tourism/hospitality industry. Journal of Tourism Research, 2, 28-35.

Schaufeli, W.B., \& Bakker, A.B. (2004). Job demands, job resources, and their relationship with burnout and engagement: A multi-sample study. Journal of Organizational Behavior, 25, 293-315. https://doi.org/10.1002/job.248

Schaufeli, W.B., Martinez, I., Marques-Pinto, A., Salanova, M., \& Bakker, A. (2002). Burnout and engagement in university students. Journal of Cross-Cultural Psychology, 33(5), 464-481. https://doi.org/10.1177/0022022102033005003

Teng, C-C. (2008). The effects of personality traits and attitudes on student uptake in hospitality employment. International Journal of Hospitality Management, 27(1), 76-86. https://doi.org/10.1016/j.ijhm.2007.07.007

Tuna, M., Kanten, P., Yeşiltaş, M., Kanten, S., \& Alparslan, A.M. (2014). The Effect of Academic Advising on Career Adaptabilities: A Study on Tourism and Hotel Management' Students. The Macrotheme Review, 3(8), 139-155.

Uludağ, O., \& Yaratan, H. (2010). The effect of burnout on engagement: An empirical study on tourism students. Journal of Hospitality, Leisure, Sport and Tourism Education, 9(1), 13-23. https://doi.org/10.3794/johlste.91.243

Wan, Y.K.P., Wong, I.K.A., \& Kong, W.H. (2014). Student career prospect and industry commitment: The roles of industry attitude, perceived social status, and salary expectations. Tourism Management, 40, 1-14. https://doi.org/10.1016/j.tourman.2013.05.004

Watts, C., \& Pickering, A. (2000). Pay as You Learn: student employment and academic progress. Education and Training, 42(3), 129-135. https://doi.org/10.1108/00400910010372670

Zhang Qiu, H., \& Lam, T. (2004). Human resources issues in the development of tourism in China: evidence from Heilongjiang Province. International Journal of Contemporary Hospitality Management, 16(1), 45-51. https://doi.org/10.1108/09596110410516552 


\section{Authors}

The contribution share of authors is equal and amounted to $50 \%$ each of them.

\section{Aleksandra Grobelna}

Doctor of economic science, assistant professor at Gdynia Maritime University at the Faculty of Entrepreneurship and Quality Science. Her research interests include tourism services, human resource management and service quality management.

Correspondence to: Dr Aleksandra Grobelna, Gdynia Maritime University, ul. Morska 81-87, 81001 Gdynia, Poland, e-mail: a.grobelna@wpit.am.gdynia.pl

\section{Anna Dolot}

$\mathrm{PhD}$, assistant professor at Cracow University of Economics, Labour Resource Management Department. Her field of interest is human resources management, specially recruitment and selection process and employees' development.

Correspondence to: Dr Anna Dolot, Cracow University of Economics, Faculty of Management, ul. Rakowicka 27, 31-510 Kraków, Poland, e-mail: anna.dolot@uek.krakow.pl

\section{Acknowledgements and Financial Disclosure}

This article was partially financed with subsidies for maintaining the research capacity granted to the Cracow University of Economics.

\section{Copyright and License}

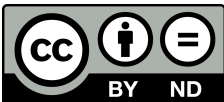

This article is published under the terms of the Creative Commons

Attribution - NoDerivs (CC BY-ND 4.0) License

http://creativecommons.org/licenses/by-nd/4.0/

\section{Published by the Centre for Strategic and International Entrepreneurship - Krakow, Poland}


